\title{
Harmonizing Conservation Values of National and Customary Laws on Turtles Conservation
}

\author{
Muhammad Yamani \\ Faculty of Law, Universitas Bengkulu \\ muhammad.yamani@yahoo.co.id
}

\begin{abstract}
Sea turtle populations on the Enggano Island are almost extinct as a result of over exploitation. This article aims to discuss harmonization of conservation values between national law and Enggano customary people in protectng sea turtles. It is found that the Enggano customary law norms have conservation values which stated prohibition of catching sea turtles by any means except for adat grandeur ceremonies (yakadea) use only. Sanctions are imposed to those who break the law with customary fines and a compulsary to apology to the chiefs and other Enggano Island communities. It is also learned that to harmonize conservation values between national law and Enggano customary law in protecting sea turtles can be conducted by implementing the norms of turtle protection in the national laws into the Village Regulation, which is an integral part of the hierarchical systems of laws and regulations in Indonesia. Harmonization of the conservation values of the sea turtles through the integration of legal substance is the best model in optimizing the protection of sea turtles without sacrificing the interests of traditional rituals that are still maintained for generations in the life of the Enggano community.
\end{abstract}

Keywords: sea turtles, conservation, customary law, Enggano

\section{A. Introduction}

Enggano island is the southernmost island located among Simenlue 
island, Nias Island, Siberut Island and Mentawai Island and on the west coast of Sumatera island. Registered in government administration, Enggano island is a sub district area and is integrated into the North Bengkulu Regency of Bengkulu Province. Enggano island has area of 68.000 hectares or $680 \mathrm{~km}^{2}$, with $40 \mathrm{~km}$ long and $17 \mathrm{~km}$ wide. Around this island, lie several small islands, namely Dua island, Merbabu island, Mega island and Bangkai island. ${ }^{1}$

The inhabitants of Enggano island comprise of five tribes who are indigenous in the Island. They are Kaahowao (originally ahua'y = ko'iyao) tribe and well known as bagug or bagug tree (melinjo/gnetum gnemon tree). The tribe of Kauno (originally ea'unno which refers to large numbers of fish swimming with the agility on the faces of sea caves and sea shores, and are beneficial for human livehood. The tribe of Kaitora (efers to itorra (terrace) wood which is very strong and hard but beneficial for human life. The tribe of Karubi, also known as eadubbi, refers to plants that grow straight up and may be as high as the surrouding plants despite their thin trunk, but also beneficial for human livelihood. The tribe of Kaharuba, originally from the word $u b a h$ 'hi refers to the preference of making innovaton as the refelection their open-minded the character like to change as an open mind. ${ }^{2}$

As the outer island, Enggano has strong custom ${ }^{3}$ in daily life, which are still valid today. One of them is the utilization of sea turtle for their traditional rituals, such as welcoming distinguished guests,

1 A. Manaf Kaarubi, Himpunan Hukum Adat dan Seni Budaya Asli Pulau Enggano (The Compilation of Indigenous Law and Native Art and Culture of Enggano Island), Lembaga Adat Pulau Enggano, 2007, p.1.

2 Ibid.

3 As will be found elsehere in this article, the phrase customary people is mostly used than other labeling such as indigenous people. The author has avoided using the last phrase as it may has pejorative meaning. In Article 1 of Paragraph (1) of ILO Convention 169 / 1989 has defined indigenous people as "being peoples in independent countries who are regarded as indigenous on account of their descent from population which inhabited the country, or a geographical region to which the country belongs, at the time of conquest or colonization or the establishment of present states boundaries and who, irrespective of their legal status, retain some or all of their own social, economic, cultural and political institution." 
removing the charm of the dead chief, appointing a new tribal chief, resettling a new village, and celebrating the new village as well as in the marriage ceremony. The Enggano adat law is believed to have conservation values for it aim at protecting sea turtles. For the needs of traditional ceremonies, the consumtion of sea turtles is inevitable. Therefore, based on their adat law the Enggano community have made every effort of conservation by limiting the number sea turtles which are allowed to be consumed. effort in the use pf sea turtles for traditional rituals by limiting the number and size of sea turtles captured. For the maximum number and size of sea turtles that are allowed to be capture. For those who capture more than 5 turtrles with a length of $60 \mathrm{~cm}$ caravas and if catching outside the customary needs and more than the stipulated provisions, a fine of money can be imposed, and it is obligatory to release the sea turtle back to the sea.

The sea turtle population in Enggano Island is reported to have been threatened with extinction due to the increasing number of consumption of turtles which used to be limited for only the purpose of traditional ceremonies. Today, turtles are also consumed at wedding parties resulting in the emergence of smuggling activities over turtles.

The government has taken steps to protect sea turtles by enforcing legal norms with sanctions, such as Article 21 of Law Number 5/1990 on Conservation of the Living Natural Resources and Its Ecosystems which that any andgulating that all persons are prohibited to:

a. Catch, injure, kill, keep, posess, care for, transport, and trade in a protected animal in Dve condition.

b. Keep, posses, care for, transport, and trade in a protected animal in dead. condition.

c. Transfer a protected animal from one place to another, within- or outside In donesia.

d. trade, keep or posess skin, bodies or other parts of a protectd animal, or goods made of parts of the animal, or transfer from one place in Indomesia to another, within or outside Indonesia. 
e. Take, destroy, exterminate, trade, keep, or posess ail egg and lor a nest of a protected animal. ${ }^{4}$

Similar effort was also taken into consideration by the functionary of the adat law of Enggano customary people who develops the content of the Enggano adat law which concerns with the protection of sea turtles, based on the adat agreements of the 6 tribes among the Enggano island community which later became the adat law of Enggano Island. Since then, harmonzation of laws is found to be important for the conservation of sea turtle. It is learned from the background of the article, the aim of this article is to understand how the conservation values in the Enggano adat law framework is related to the protection of sea turtles and to elaborate how the harmonization on conservation values in the national and customary laws would protect sea turtles without sacrificing the interest of local traditions.

\section{B. Research Methods}

Andry Harijanto Hartiman ${ }^{5}$ revealed that one of the practices of exploitation of natural resources is over sea turtles that have been and are still happening in Enggano Island. He recommends environment and natural resources be conserved and managed by optimizing Enggano customary law. He argues is that natural resource management based on adat law will have positive impact to reduce the level of environmental damage in the Island which is classified as vulnerable.

Similarly, Jaja Mulyana, during his observation as the head of section of the region one covering the conservation area in the Island, has come to the conclusion that until now the utilization of sea turtles has not followed the right and correct methods resulting in imbalancy of between the level of utilization and the level of turtle

4 The translation is provided by the author.

5 Andri Harijanto Hartiman, "Ketaatan Otomatis Spontan Pada Hukum Adat Studi Kasus Dalam Masyarakat Suku Enggano" (Spontaneous Automatic Adherence to Customary Law: Case Studies of Enggano Tribes Communities)," Jurnal Penelitian Hukum, Year III, VI Edition, Number 1, January 1998, p. 32 . 
population growth. Excessive exploitation, regardless of its protection, has caused the status of the natural turtle population becomes increasingly endangered.

Andri Rahmat (2016), a Bengkulu Universtity student, on his study on the utilization of sea turtles in the Island, revealed that in the adat rituals on Enggano Island, sea turtles are consumed and captured unlimitedly by the community as many as they catched from their hunt. On the other hand, the chief of Enggano Island explained that based on their custom, the Enggano community have made conservations in utilizing the sea turtles for their adat rituals by limiting the number and size of turtles being captured. The maximum numbers of sea turtles that are allowed to be captured are 5 with the $60 \mathrm{~cm}$ length of carapace. Catching more than the needs of the traditional ceremonies and beyond the applied reles will be fined to $\mathrm{Rp}$ 2,500,000.00 (two million five hundred thousand rupiahs). In case of being caught to capture or found to keep sea turtles, he or she shall release the turtles back to the sea.

Applying a sociological juridical approach, this article aims at observing how the rule of law works in society which is rooted in social acceptance. It provides perspective of law in a social context, analysis of the effectivity of law in society, both as a means of social control and social change as well as social interaction in order to achieve certain social justice. ${ }^{6}$ Through this approach, it is hoped that values of local law can be achieved, in this concern is the conservation value of turtle protection in the Enggano adat law, compared and harmonized with the value of the turtle conservation in the existing law.

The study was conducted in Enggano Island which covers the territory of the customary people of the Kaitora, Kaahoaa, Kaarubi, Kauno and Kaharuba tribes, who settled in the villages of Malakoni, Apoho, Meok and Kahyapu, where adat ceremony of consuming sea turtles is performed. Informants of the study included non formal legal officers namely functionaries of adat Enggano representing 5 tribes of Kaitora, Kaahoaa, Kaarubi, Kauno and Kaharuba, and com-

6 Soerjono Soekanto, Pokok-Pokok Sosiologi Hukum (Principles of Legal Sociology), Jakarta: Rajawali Pers, 1994. 
munity members from other 5 customary people where the study was conducted based on their skills and broad of knowledge, concerning the utility of sea turtles and the traditional ceremonies.

Primary data was obtained through interviews and focussed discussion throughout the reserach process to re-evaluate research findings, information, and interpretation with informants to strengthen the opportunities for harmonizing conservation values between local wisdom (adat law of Enggano) and the existing law. Data was analyzed using qualitative methods including 4 technics of data analysis, namely domain analysis, taxonomy analysis, componential analysis and cultural theme analysis, ${ }^{7}$ which is closed with conclusions using inductive reasoning.

\section{Research Results and Discussion}

\section{Conservation Values in the Enggano Customary Law Order Relating to Turtle Protection}

The research revealed that the practice of hunting turtles in the tradition of the customary people in the Enggano Island is originally intended to meet consumption needs in great adat ceremonies (yakadea) which are exercised in every form of marriage celebrations or transfers or reaffirmations of the name of the tribal village according to the local adat, the inauguration of the elected chief. In performing the traditional ceremony, the main serve is always turtle meat. It is reported that the great adat ceremony (yakadea) is not considered without turtle meat as it is a symbol of a traditional ceremony."

Bassically, the tradition of hunting and consuming turtles as long as it is carried out only for adat ceremonies (yakadea), it would not cause extinction of these protected endangered species. Moreover, in the customary law of the Enggano Island customary people, there are criteria of size and number of sea turtles that are allowed to be

7 Sanapiah Faisal, Penelitian Kualitatif Dasar-Dasar dan Aplikasi (Qualitative Research: its Principles and Applications), Malang: Yayasan Asih Asah Asuh, 1990, p. 90.

8 Interview with Pabuki leader of the Enggano tribe, 2017 
caught. It is learned from the interview with the Chief of the Kaitora tribe, that the practice of catching sea turtles is carried out according to the needs to only 5 to 6 turtles, with the criteria of comsumability and maturity of turtles. The limitation of hunting turtle is motivated by the fact that the turtle population in the Enggano sea waters begin to decrease. In the past, the turtles captured could weigh up to $300 \mathrm{~kg}$, and that used to become the criteria cosumable turtles. It is found that the existence of customary rules limiting the number and criteria of sea turtles shows the commitment of the local people to avoid over exploitation of the turtles. ${ }^{9}$

However, the turtle sustainability in Enggano sea waters is increasingly threatened due to the failure of the implementation of Enggano adat (customary) law. In addition, the depelovment of sea turtle consumption is not only limited to the traditional ceremonies, but also to other purposes, such as ceremonies for the death of one of the tribesmen, ceremonies of donation for traditional greatness (padabuki), traditional ceremonies in the context of small adat peace (yakodoa yahobba), and large peace according to traditional ceremonies (yakodoa kaodada). Along with tradition of traditional ceremonies with the main consumption of sea turtle meat, until now there has been no effort taken by the central government and the local government to empower the Enggano community to conduct sea turtle breeding as a solution to meet the needs of turtles in the traditional ceremonies.

Enggano customary law developes based with the changing times and the needs of life of the Enggano people. Observing the birth of the adat law of Enggano, there is no such value relating to the conservation of natural resources. Rather it is only limited to regulating relation and private lives among the members of the Enggano customary people, such as the rule of adat law regarding protection of life, dignity, and honor in social status, and customary rules regarding the pattern of relations between the members of the Enggano customary people and the territorial land belonging to the

9 Interview with the Chief of the Kaitaro tribe, 2017 
Enggano customary people.

As for the adat law relating to conservation, it develops together with the knowledge of the members of the Enggano customary law community on the environment and environmental resources themselves. The knowledge, respectively, creates awareness among the people in utilizing environmental resources. For example, the birth of customary law of Enggano which prohibits the activity of hunting turtles unlimitedly might be inspired by the people's understanding on the Law Number 5 of 1990 concerning Conservation of Living Natural Resources and Its Ecosystem.

This research found legal facts that the development of the substance of Enggano adat law that contains conservation values are believed to begin after the enforcement of national law. The substance of the Enggano adat law is found in the agreement document contained in the Decree of the Chieftain in 2009 concerning the management of natural resourcess, animals, as well as land clearing, management and conservation of the Enggano Island coastal area in the effort of avoiding Enggano Island from abration. The agreement is the culmination of the development of the Enggano adat law which has conservation value as a progress of thinking influenced by knowledge on the existing law. Since then, Enggano adat law has customary law norms that govern environmental conservation.

The rules in the adat law of Enggano which where enancted as a concern of the Enggano community with their needs of the turtles, as long as the conservation of environmental resources are concerned, can be understood, among others, from the rules concerning the protection of sea turtles, particularly with regards to marine and river products, formulated in a customary law ass follows:

Turtles area strictly prohibited from being taken or traded. Enggano communities are allowed to breed turtles prior to applicable provisions and adat procedures of the Enggano Island.

To capture sea turtles, for the Enggano customary people, especifically for traditional events or traditional parties, is permissible to merely fulfil the need of the traditional events. 
Sanction for violating these rules are subject to traditional fines to Rp. 2,500,000.00 (two million and five hundred rupiahs) and compulsory to perform a traditional ceremony inviting the chiefs and traditional leaders to apologize with. For those who catch sea turtles without prior permission of the local government and tribal leaders, the legal process will apply. ${ }^{10}$

The enacment of the adat law that reflects the concern of the customary functionaries of the Enggano customary people with the threat over the sustainability of environmental resources, including various types of sea turtles whose existence in the waters of the Enggano Island is dominishing. As long as the enacment of the Enggano adat law is concerned, the view of the school of history which was developed by Von Savigny seems to be relevant with this respect. It says:

There is an organic relationship between law an the character of a nation. Law is only a reflection of volkgeist, Therefore customary law which grows and develops in the volkgeist womb must be seen as the true law of life. True law is not made. He must be found. Legislation is only important as long as it has the declarative nature of the true law. There needs to be indepth research on what the spirit of the nation really is, and which national beliefs can be the basis of an adequate legal system. ${ }^{11}$

In the latest developments, the Enggano customary law no longer allow the hunting of turtles arbitrarily, both for consumption and trade, with the affirmation that the utility of sea turtles shall be limited to traditional ceremonies only. This was stated among the agreement of the tribal chiefs who declared, through customary law, that "it is strictly prohibited to be cought or traded."

The protection of sea creatures seem to have taken world attention. Emmy Latifah proposes precautionary principle as long as the management of sea creatures is concerned. In her elaboration on this matter, precautionary is inseparable with the management, one of which is to plan. The plans may include specific management objectives, specific operational targets and constrains, procedure to apply

10 The translation is provided by the author.

11 Bernard L. Tanya, et.all, 2013, p. 94-95. The translation is provided by the author. 
and adjust management measures, and prospective evaluation. ${ }^{12}$ This article proposes that the participation of the local people ${ }^{13}$ would work more efficiently than just enforcing laws in which local wisdom is main key to put forward in protecting sea turtles. In this regard, the local community may take a part ${ }^{14}$ in utilizing the turtles in a wise manner. Enggano communities are allowed to breed turtles, but shall not go beyond the applicable provisions and customary procedures applicable in the Enggano island. For the purpose of consuming sea turtles, the Enggano customary people are allowed to catch them only for traditional events or traditional parties. The prohition of catching turtles is equiped with customary sanction, namely by performing special a traditional ceremony for the purpose of apologizing before the chiefs and elders of the Island, yet still consider the possibility to be processed according to the national law.

\section{Harmonization of Conservation Values of the National and Customary Laws on the Protection of Sea Turtles}

The attention of the Indonesian government towards the conversation of sea turtles began after the sgining of CITES 1973, which was followed up by ratifying the international agreement into Presiden-

12 Emmy Latifah and Moch Najib Imanullah, "Applying Precautionary Principles in Fisheries Management,” Jambe Law Journal, Vol. 1 No.1 (2018), p. 26-27.

13 As it is mention elsewhere in this article, the local people of Enggano Island comprise of customary people. Today, the recognition of the customary people before the cosntitution has taken wide attention from activists and academics. Muhammad Dahlan has pointed out that the recognition of the customary people is important to set them free of choosing their own law and developing their justice system. With regard to the turtles protection, the recognition of the customary people would grant them an indipendence to regulate the their local wisdom as long as the protection of the turtles is concerned, yet still in line with the national law. See Muhammd Dahlan, "Rekognisi Hak Masyarakat Hukum Adat dalam Konstitusi (The Recognition of the Customary People before the Constitution)" Undang: Jurnal Hukum, , Vol. 1, No. 2 (2018), p. 198.

14 Compare with Taufik Yahya and Fauzi Syam, "Rethinking the Role of Indigenous Law Community in Managing Indigenous Forest in Jambi Province," Jambe Law Journal, Vol. 1 No.1 (2018). 
tial Degree Number 43 of 1978 concerning CITES (Convention on International Trade in Endangered Species of Wild Fauna and Flora) or the International Convention Governing Trade Wildlife and Endangered Plants, as contained in State Gazette Year 1978 Number 51.

The national legislation policy which is driven by concern for the protection of turtles that are increasingly threatened with extinction, has finally been relaized by esthablishing law Number 5 of 1990 concerning Conservation of Living Natural Resources and Ecosystems, which implicitly regulates the protection of sea turtles, as regulated in Article 21 which reads:

(1) Everyone is prohibited from:

a. taking, cutting, possessing, destroying, maintaining, transporting and trade in protected plants or parts thereof living or dead;

b. removing protected plants or parts thereof in life or death from a place in Indonesia to other places inside or outside Indonesia.

(2) Everyone is prohibited to:

a. capture, injure, kill, store, possess, care for, transfort and trade protected animals in a state of life;

b. storing, possessing, maintaining, transforting and trading protected animals that are dead;

c. eject protected animals from one place in Indonesia to other places inside or outside Indonesia;

d. trade, store or posses skin, body or other parts of protected animals or items made from animal parts or remover them from a place in Indonesia to other places inside or outside Indonesia;

e. take, destroy, trade store or own eggs and/or nests of protected animals. ${ }^{15}$

Prohibited acts as regulated in Article 21 of Law Number 5 of 1990, both carried out "intentionally" or because of "negligence", are threatened with criminal offenses, with qualification for violations, as regulated in Article 40 paragraph (2) and (4) which reads:

Paragraph (2):

15 The translation is provided by the author. 


\section{Muhammad Yamani}

Whoever intentionally violates the provisions refrred to in article 21 paragraph (1) and paragraph (2) and article 33 paragraph (3) shall be sentenced to a maximum imprisonment of 5 (five) years and a maximum fine of Rp100,000,000,00 (one handred million rupiahs).

Paragraph (4):

Whoever, for his negligence, violates the provisions referred to in article 21 paragraph (1) and paragraph (2) and article 33 paragraph (3) shall be liable to a maximum imprisonment of 1 year and a maximum fine of $\mathrm{Rp}$ $50,000,000,00$ (fifty million rupiahs). ${ }^{16}$

The Indonesian concern with the protection of sea turtles has put into reality Government Regulation Number 7 / 1999 concerning Preservation of Plants and Animals, which is the implementation of Law Number 5 of 1990 concerning Conservation of Biological Resources and Their Ecosystems, in the number III Reptilia (Reptile) of its attachment explicitly establishes protections of sea turtles covering loggerhead turtles (caretta), green turtles (Chelonia mydas), leatherback turtles (Dermochelys coriacea), hawksbill turtles (Eretmochelys imbricata), ridel turtles (Lepidochelys olivacea), flatback turtles (Natator depressa).

Indonesia has also signed the 1992 Biodiversity Convention, ratifying it through Law Number 5 of 1994 concerning Ratification of the United Nations Convention on Biological Diversity. Considerations consider the act, among others, emphasizes that "biodiversity is expierencing significant reduction and loss due to certain human activities that can cause disruption of the balance of life systems on earth, which in turn will disrupt human life."

Sea turtles protection regulations might have considered the possibility of continuous practices of traditions among the customary people in consuming sea turtles, as in the case of the traditional rituals and weddings among Enggano Island communities. The national law as long as the sea turtles protection is concerned continues to accommodate the local tradition of the Island by providing opprotunities for the use of sea turtles and their parts including their

16 The translation is provided by the author. 
eggs in accepted ways, through such activities as breeding turtles, the implementation of which shall have permission from an authorized instituion, as it is regulated in the article 52 of the Government Regulation number 8 / 1999 concerning Utilization of Wild Plants and Animals Species:

(1) Whoever breeds wild plants and/or wild animals without a permit as referred to in Article 9 paragraph (1) may be subject to an administrative penalty of up to Rp25,000,000.00 (twenty five million rupiahs) and/or revocation of captivity permit.

(2) If the act referred to in paragraph (1) is carried out on protected plants and/or animals punished for carrying out prohibited acts according to the provisions of article 21 of Law Number 5 of 1990 concerning Conservation of Biological Natural Resources and their Ecosystems. ${ }^{17}$

In case of legality for consuming special type of turles, such as green turtles (Chelonia mydas) and hawksbill turtles (Eretmochelys imbricata), it requires a condition in which the number of the turtles are over and their habitat is outside the conservation area. The legality to utilize turtle eggs is based on the provisions stipulated in the Decree of the Minister of Forestry and Plantation Number 751/ Kpts-II/ 1999 concerning Procedures for Application, Granting and Revocation of Business License for Hunting for Green Turtles (Chelonia mydas) and hawksbill turtles (Eretmochelys imbricata).

It is learned from the reseach tha fact that the messages cotained anywhere in international conventions and national law in the field of turtle protection will not be applicable in the protection of sea turtles in the waters of Enggano island, one of which is due to the regulation on turtle protection implemented in the Enggano customary law.

The protection of sea turtles in Enggano Customary Law shows the development of a substance that is slowly moving towards the adjustment to the national legislation. This is true from the Enggano adat law which regulates sea and river products, including the norms formulated in the adat law which state: "crocodile / turtles are forbidden to be catch or traded."

17 The translation is provided by the author. 
It is understood from the agreements in international conventions, the provisions in the legislation, as well as the Enggano adat Law as long as the protection of sea turtles is concerned, the conservation values of the sea turtle protection in the Enggano adat Law (positive unwritten law) have in common of conservation values with the ones in the national laws (positive written law), even to its process of enactment which was strongly influenced by national law, despite their differences in the form and type of sanctions; the adat law prefers customary sanctions enforced in such forms as paying sum of money and social sanction ${ }^{18}$ by performing a traditional ceremony where the innocent declares his / her apology before the chief of the tribe.

Rooms to harmonize conservation values contained in national laws (positive written law), can be taken through the institutional approach of village governance, by utilizing the authority that is already possesed by the village government to further regulate the provisions of state (national) laws with regards to the protection of sea turtles to be enforced in to the Village Regulation concerning turtle protection.

Lastly, the means to harmonize the legal substance of turtle protection is regulated in the Adat Village Regulation concerning turtle protection, which is part of the hierarchical system of laws and regulations in the Indonesian legal system. Harmonization of turtle conservation values contained both in the customary law (living law) and conservation values in the national laws, is the right solution, so that traditional ceremonial traditions can be maintained, and turtles can be protected from extinction.

18 Mostly, adat sanction ranges from fine to social sanction. Such practice is found among the Tribe of Dayak Wehea in Nehes Liah Bing Village. For further information about the adat sanction in this community, see Yogi Hardiman, Siti Kotijah, and La Sina, "Restorative Justice Terhadap Pelaku Tindak Pidana Ringan yang Telah diberi Sanksi Adat (Restorative Justice for the Perpetrator of Minor Offence who Has Charged with Adat Sanction), Mulawarman Law Review, Volume 4, Issue 1, June 2019, p. 6. 


\section{Conclusions}

Conservation values on sea turtles as the substance of the Enggano adat law are learned to have formulated a prohibition on catching sea turtles for all needs, except for the necessity of ceremonial great ceremony (yakadea). The provisions of made by the chief of the tribe is to guarantee the adherence of the Enggano community to the rules of the adat law to protect sea turtle. To harmonize the conservation values between the national law and the Enggano adat law with regards to the protection of sea turtles can be applied by imposing the norms of sea turtle protection in the national laws into the Vilage Regulation. In another way, the Village Regulation can be integrated as part of the hierarchy of laws the Indonesian legal system in which the obligation to breed turtles shall be imposed to the customary peoples so that they can utilize the turtles for the needs of their traditional ceremonies and wedding ceremonies. Harmonizing the conservation values of sea turtles by integrating the legal substance (Acts, Government Regulations, Village Regulation) is believed to be the best alternative in optimizing the protection of sea turtles without sacrificing the interest of traditional rituals that are still maintained for generations in the life of the Enggano community.

\section{Bibliography}

\section{Legal Documents}

Law Number 5/1990 on Conservation of the Living Natural Resources and Its Ecosystem (Undang-Undang Republik Indonesia Nomor 5 Tahun 1990 Tentang Konservasi Sumber Daya Alam Hayati Dan Ekosistemnya)

Government Regulation Number 7 / 1999 concerning Preservation of Plants and Animals (PP Nomor 7/1999 Tentang Pengawetan Jenis Tumbuhan Dan Satwa)

Decree of the Minister of Forestry and Plantation Number 751/ Kpts-II/1999 concerning Procedures for Application, Granting and Revocation of Business License for Hunting for Green Turtles (Chelonia mydas) and hawksbill turtles (Eretmochelys im- 
bricata)

\section{Books}

A. Manaf Kaarubi. 2007. Himpunan Hukum Adat dan Seni Budaya Asli Pulau Enggano. (The Compilation of Indigenous Law and Native Art and Culture of Enggano Island). Lembaga Adat Pulau Enggano.

Andri Harijanto Hartiman, "Ketaatan Otomatis Spontan Pada Hukum Adat Studi Kasus Dalam Masyarakat Suku Enggano" (Spontaneous Automatic Adherence to Customary Law: Case Studies of Enggano Tribes Communities)," Jurnal Penelitian Hukum, Year III, VI Edition, Number 1, January 1998, Faculty of Law Universitas Bengkulu.

Bernad Steny, 2006. "Plurasisme Hukum: Antara PERDA Pengakuan Masyarakat Adat dan Otonomi Hukum Lokal" (Legal Plurasism: Between Regional Regulation on Recognition of Customary peoples and the Autonomy Local Law”, Jurnal Pembaruan Desa dan Agraria Vol III, Year III, 2006, Institut Pertanian Bogor, Bogor.

Depdikbud RI. 1995. Kamus Besar Bahasa Indonesia (Indonesian Dictionary). Jakarta: Balai Pustaka.

Faisal Sanapiah. 1990. Penelitian Kualitatif Dasar-Dasar dan Aplikasi (Qualitative Research: its Principles and Applications), Malang: Yayasan Asih Asah Asuh.

Mochtar Kusumaatmaja, 2002, Konsep-konsep Hukum dalam Pembangunan (Legal Concepts in Development), Bandung: Alumni.

Lili Rasjidi \& IB Wyasa Putra, 1993, Hukum Sebagai Sistem (Law as a System), Bandung: Remaja Rosdakarya.

Soerjono Soekanto. 1994, Pokok-Pokok Sosiologi Hukum (Principles of Legal Sociology), Jakarta: Rajawali Pers.

\section{Journals}

Dahlan, Muhammd, 2018, "Rekognisi Hak Masyarakat Hukum Adat dalam Konstitusi (The Recognition of the Customary People before the Constitution)" Undang: Jurnal Hukum, Vol. 1, No. 2. Hardiman, Yogi, and Siti Kotijah, and La Sina, 2019, "Restorative Jus- 
tice Terhadap Pelaku Tindak Pidana Ringan yang Telah diberi Sanksi Adat (Restorative Justice for the Perpetrator of Minor Offence who Has Charged with Adat Sanction), Mulawarman Law Review, Volume 4, Issue 1, June.

Latifah, Emmy and Moch Najib Imanullah, 2018, "Applying Precautionary Principles in Fisheries Management," Jambe Law Journal, Vol. 1 No.1.

Yahya, Taufik and Fauzi Syam, 2018, "Rethinking the Role of Indigenous Law Community in Managing Indigenous Forest in Jambi Province," Jambe Law Journal, Vol. 1 No.1. 